\title{
THE EDUCATION AND HIRING OF SPECIAL COLLECTIONS LIBRARIANS: OBSERVATIONS FROM A RECENT RECRUIT
}

THE TOPIC OF WHAT SKILLS and qualifications are required of special collections librarians has come up in numerous places in past months, including in an Association of Research Libraries (ARL) White Paper released in November 2004 and at the most recent (June 2005) Rare Books and Manuscripts (RBMS) Preconference in St. Louis. Not coincidentally, it also was the focus of a roundtable session at the April 2005 Association of College and Research Libraries (ACRL) National Meeting in Minneapolis. This article summarizes the discussion at the latter event and points out how several themes have been recurring in other contexts. Those themes are the focus of the second part of this article, offering one early-career librarian's observations on the current state of education for aspiring special collections librarians and what can be done to improve it.

The Round Table at ACRL 2005: Hiring a Special Collections Librarian: The Skills, the Qualifications, the Challenges in Recruitment

The RBMS Round Table was held during the lunch-hour time slot on Saturday, April 9, 2005, at the ACRL National Meeting in Minneapolis. Co-organized by Hjordis Halvorson (Newberry Library), Beth Russell (Ohio State University Libraries), and this author, the session was intended to address an audience of librarians who might not currently work in special collections, but who are interested in issues related to special collections. The session attracted a sizeable crowd. Participants included librarians from academic institutions and private research libraries, and a librarian from the U.S. Army. Still more encouraging was the attendance by those outside the usual RBMS circle, including an administrator in human resources for an institution that was currently posting a special collections position, a library school administrator, and 
several early-career librarians interested in pursuing special collections positions.

The session began with a discussion of the core skills that are traditionally sought in a rare books librarian, including knowledge of descriptive bibliography, reference work with primary sources, and preservation and subject knowledge. Proficiency in multiple languages is still considered vital, but the range now expands beyond European languages and Latin to include Arabic and East Asian languages, as seen in the example offered by the Army librarian, whose collections document the Korean and Viet Nam wars.

The group also offered examples of additional skills that are becoming important. One particularly insightful observation was the fact that special collections librarians now need to have a good working knowledge of copyright and intellectual property issues. Our increasing work with digital material, both "born digital" and that created from paper collections, as well as the demand for digital reproductions for researchers and the media, have required special collections librarians to confront copyright and intellectual property issues in new ways, including establishing policies for preservation and use that will carry these digital collections into the future. Although adding a law degree to our list of qualifications may be premature, special collections librarians will need a thorough understanding of the legalities surrounding image permissions, copyright, and intellectual property, as well as the ability to communicate with lawyers so that our collections are better served and protected by decisions made regarding intellectual property.

Conversation at the roundtable session next turned to education for special collections librarians. At present, most course work focusing on rare books is offered in the "continuing education" mode. The group was not satisfied with this status quo. Although there was general agreement that the education provided by workshops, seminars, and institutes such as Rare Book School (RBS), is valuable, this should not be the only way to obtain rare book training. ${ }^{1}$

1. Rare Book School, an independent educational institute directed by Terry Belanger and located at the University of Virginia, is a cornerstone of rare books education in the U.S. For more information on the program and the courses offered, see the school's Web site at http:// www.virginia.edu/oldbooks/. 
At this point, a library science graduate program administrator expressed her frustration and raised a key issue. To paraphrase her words: there's little reason to wring our hands over education if there are no jobs for graduates to take upon graduation. She argued that there is a significant lack of entry-level positions in special collections librarianship; postings for higher-level positions are more common (perhaps because many units have only one professional staff member). Even postings for nonadministrative positions often require several years of experience, leaving few opportunities for graduates to enter the field directly out of library school.

\section{The ARL White Paper: "Education and Training for Careers in Special Collections"}

These same concerns over education and entry-level positions are among the findings of the White Paper published by the Special Collections Task Force for ARL in November of 2004..$^{2}$ Indeed, one need look no further than the second paragraph in the document to find this summary of the state of the profession: "There is a need for recruitment, education, and training of special collections at all career levels ... but limited educational opportunities and entry-level positions pose obstacles to entering the profession." Author Alice Schreyer goes on to note that library directors are reporting problems in filling positions with qualified candidates, particularly for senior positions, whereas librarians in the early stages of their careers are finding it difficult to enter the profession through the few entry-level jobs that are available. This crisis will only grow more severe in years to come, because a third of senior managers in rare books and special collections will reach retirement age by the year $2010 .^{3}$

The White Paper addresses library education as well, noting that curriculum changes and the closure of many library schools have left few accredited programs offering any sort of rare books training. However, hope can be found in the partnering of the Palmer School of Library and Information Science of Long Island University with the Rare Book School to offer credit for RBS courses. Some individuals are electing to study within the archival community, as programs in archives and records management are much more easily found. Joint MA-LIS degrees

2. Alice Schreyer,"Education and Training for Careers in Special Collections-A White Paper Prepared for the Association of Research Libraries Special Collections Task Force” Nov. 2004). The paper is available online as a PDF document at the ARL Web site: http://www.arl.org/collect/spcoll/SCTF.ED.pdf

3. Ibid., 4 . 
are possible or, alternatively, LIS degrees with an archives emphasis. Further information can be found on the RBMS Web site, which includes a directory of ALA-accredited library schools. Each entry provides a basic description of the school and a listing of the courses related to archives and special collections that each one offers, including the crucial detail of how often those classes are available. ${ }^{4}$

\section{The RBMS Preconference: "Bridging the Gap: Education and Special Collections"}

The 2005 RBMS Preconference addressed the role of special collections librarians as educators and the education of special collections librarians. In her plenary address, Deirdre Stam, of the Palmer School of Library and Information Science, Long Island University, provided useful observations on how new graduates can gain experience and recommended a variety of professional networking opportunities and internships.

The suggestion about internships was raised in less obvious places as well. In the preconference seminar entitled "Going Over to the Dark Side: Librarianship and the Book Trade," book dealer Howard Rootenberg described the efforts of the Antiquarian Booksellers Association of America to develop internships that would place students with rare book dealers as another venue for obtaining valuable rare book experience. Like libraries, the antiquarian book trade has need of new recruits.

Several speakers discussed graduate-level educational programs.Although many library schools list courses in rare books and special collections in their course catalogs, those classes may be offered infrequently, or no longer offered at all, such as in cases where faculty members have left or retired. Archives education is better in this regard, but it is still not immune to the problem. Elizabeth Yakel, a faculty member at the University of Michigan's School of Information, presented the results of her recent survey of archival education programs. She noted startling discrepancies between the number of archives courses listed and offered, even by some of the best-established archives and records management programs within library schools. ${ }^{5}$ In sum, though the state of educa-

4. See "Educational Opportunities:A Directory" under the "Resources" menu on the RBMS Web site, or go directly to http://www.rbms.nd.edu.

5. It is to be hoped that Yakel's comments will be available in a future publication. Her previous work on the subject of archival education programs is presented in "The Future of the Past:A Survey of Graduates of Master's-Level Graduate Archival Education Programs in the United States," which is currently available at http://www2.sis.pitt.edu/ gaeconf/yakel.html. 
tional opportunities for archives training might look better on paper, in practice it may still prove difficult to complete a full curriculum of archives-focused classes. The savvy student will ask about upcoming course offerings before choosing a library school.

\section{The Perspectives of an Early-Career Librarian}

In the interests of full disclosure, allow me to summarize my own entry into the profession. Like many of my colleagues, I was introduced to special collections librarianship while working in the library at my undergraduate institution. The special collections department was not a large one, but it held an intriguing number of rare books and archives, including an extensive collection of photographic prints and negatives documenting steamboat traffic on U.S. inland waterways.As was the case with many college freshmen, steamboat history wasn't high on my list of passions at the time,- - but as I soon found out, learning a little bit about a subject can open up a whole new field of interest. And that's what convinced me-rare book librarianship is a career that offers unlimited opportunities for learning. I completed an MA in history and then went to the University of Michigan for a library degree, and was fortunate to pursue a concentration in archives and records management in a program where archives courses are offered on a regular basis. It was with that background that I entered the working world, starting at an imaging firm that provided microfilming and digital scanning services to libraries and archives. After several years in the private sector, I moved back into the academic realm and became assistant curator at the James Ford Bell Library, a rare book and map collection at the University of Minnesota.

It is with that perspective-an archives-trained, library-degree-holding, beginning academic librarian - that I survey the professional landscape. To an early-career librarian like myself, the state of current educational opportunities for special collections librarianship is decidedly mixed, though there is some reason to be optimistic. On the positive side, continuing education opportunities abound. Rare Book School offers excellent courses, skilled instruction, intensive learning opportunities, and a collegial atmosphere that has been the source of numerous rewarding and long-lasting professional relationships. The commendable success of the program at the University of Virginia has spawned sister programs, institutes, and course offerings around the country and, indeed, the world. Rare Book School attendees often describe the experience as a genuine pleasure, one of those rare professional "treats" that are to be savored. 
But although continuing education is available, education courses for working with rare book collections within library schools remain all too elusive. The great advantage enjoyed by degree-granting programs is that they usually have financial support available for their students, often in the form of graduate assistantships (which, in the best instances, can provide both tuition relief and health benefits). Options such as Rare Book School are wonderful and vital-but they are expensive for those without financial assistance, particularly students or graduates seeking the training that will lead to a job in special collections. For those professionals who are already employed and wish to pursue continuing education opportunities, many academic institutions offer some financial support—but it may only partially cover expenses. For professionals at nonresearch/academic libraries, the availability of support is less certain, particularly if the course of study is not immediately relevant to current job responsibilities.

Choosing courses in archives and records management programs within library schools is another option, as previously mentioned. Archives programs have become well established in a number of accredited library schools around the country, and a possible survey of current early-career special collections professionals might reveal a great number who have chosen to take this route to obtain a relevant education. It is certainly a logical choice to make, particularly given the number of special collections departments that have archival collections, but it has definite limitations for rare book librarians. The set of skills required to work with rare book collections is not identical to that required for working with archival collections. Archives training is complementary to rare book librarianship, particularly as the latter often offers courses in preservation and primary source reference, but it would still be necessary for rare book and special collections librarians to obtain training, often through continuing education, in such areas as history of the book, descriptive bibliography, and rare book cataloging.

Fortunately, we are at an opportune moment to address this need. The ARL White Paper began a conversation about education and training, providing a survey of the current educational landscape. This conversation was continued at the 2005 RBMS Preconference, most notably in the comments of Deirdre Stam and Beth Yakel on the state of library school. It is an excellent time for RBMS to become more active in encouraging new directions in providing opportunities for the education of rare book librarians, including maintaining an ongoing dialogue 
with library schools and encouraging the teaching of rare book classes in existing archives and records management programs.

As both the ACRL Round Table and the ARL White Paper indicate, the skills and knowledge required for working with special collections are changing, and to that end, exposure to areas of librarianship outside rare books and special collections can be quite advantageous. Development and fundraising work are becoming a vital part of the special collections mission as library directors focus on those collections that uniquely distinguish an institution. Digital technology and knowledge of the legal issues accompanying the creation and use of digital materials are a fact of modern special collections life. As Alice Schreyer points out in the WhitePaper: "Previously distinct job categories, often format-based, are blurring; and special collections librarians need to have a holistic understanding of the profession." 6

There also is very good news regarding the financial support available for continuing education. The directors of the Rare Book School have always been conscious of the need for financial support for attendees and consequently have been generous in offering scholarships. This effort will be helped greatly by a generous grant from the Institute of Museum and Library Services to support fifty scholarships each for the years 2006-2008 as part of the IMLS Librarians for the 21st Century program. Likewise, RBMS has been able in recent years to offer competitive scholarships to RBMS preconferences. In support of the 2006 preconference, ACRL has received a $\$ 93,106$ grant from IMLS, a large portion of which will provide thirty scholarships for new and aspiring special collections and museum professionals. This is welcome news for new professionals and for students who may wish to supplement a library school program with rare book classes that they take outside the curriculum.

Multiple speakers at RBMS, including librarians and those in the book trade, have promoted internships. They are undisputedly a valuable experience for students, offering both preliminary experience and a tantalizing glimpse into life in the profession, and the combination of an internship with a library degree would make a recent graduate a very attractive prospect for most entry-level positions. However, as noted in the ARL White Paper and at the ACRL Round Table discussion, entrylevel positions are scarce. An internship will not suffice for the multiple 
years of on-the-job experience that is the common requirement of the majority of rare books/special collections job postings. Although internships are experiences that should be encouraged for students and young professionals, our profession cannot rely on them to offer sufficient opportunities for new librarians to achieve the experience needed to obtain the jobs that are currently on the market.

And what about those jobs being advertised? What skills and experience are the job postings requiring? A survey of the listings in the posting services for ALA, ACRL, the Society of American Archivists, and the Chronicle of Higher Education for the months of April through June 2005 shows that among the postings in special collections positions (broadly defined to include archives, records management, rare books, and manuscripts collections), thirty-six of the forty-two required previous library work experience. ${ }^{7}$ Some required that the experience be specifically in a special collections unit; others simply asked for library experience, regardless of the type of skills employed (most phrased it as "relevant library experience"). One posting required one plus years of experience; most others ranged from three to five years as a minimum. Interestingly, a few postings identified more general requirements, incorporating phrases such as "considerable experience," thus allowing for a wider range of candidates to be considered. This is even more noticeable in postings from nonacademic institutions and corporations (e.g., a major U.S. beverage company that was searching for an archivist). These job descriptions are drafted from the perspective of business communities that are accustomed to framing positions broadly and thinking very flexibly about the individual they wish to hire. Of those job postings that did not require experience, only one explicitly encouraged new graduates to apply-and notably, it was a digital collections position seeking applicants with cutting-edge technology skills.

In general, there are significantly more postings for archivists, including many at the entry level. The job posting service provided by the Society of American Archivists (SAA) offered the most listings: twenty-seven of the jobs included in my survey came from that site alone. In light of this fact, students who choose to pursue archival education tracks within library schools may be on the right track. But if that is to be the case,

7. Conversation at the ACRL Round Table touched on the issue of common venues for posting special collections positions; these four posting services all were cited by those in attendance, with the Chronicle being the most consistently cited venue across the institutions represented. 
there is all the more impetus for RBMS to encourage the active teaching of rare books classes within existing archives programs.

In sum, at present, the route into special collections librarianship is not always a straight and well-marked path and students will face some hardships to get into the profession, particularly if they want to work as rare book librarians. That probably doesn't surprise anyone already working in the field. So why is it so significant? Because it has direct impact on who enters our profession and on our ability to recruit people to join us. At a time when RBMS is making a conscious and strategic effort to promote diversity within the ranks of special collections librarians, we cannot ignore the stumbling blocks - whether financial, educational, or otherwise-that make it difficult to enter the profession. If library school graduates are unable to gain entry-level experience in special collections departments, they will have to take positions in other departments-and this is risky. They could enjoy those jobs and decide to stay, and so we would lose them before they ever join us. We need to offer more "intentional" routes into this career, with educational opportunities that provide tuition support and jobs that provide special collections experience to recent graduates. 